\title{
UN Peace Operations and Changes in the Global Order: Evolution, Adaptation, and Resilience
}

\author{
Cedric de Coning
}

\section{INTRODUCTION}

At the end of the twentieth century, most peacekeepers were engaged in implementing comprehensive peace agreements. Today, only a decade and half into the twenty-first century, most UN peace operations have undergone a significant phase-shift and are now focused on stabilisation and protection of civilian roles. Why have peace operations changed its core role from conflict resolution to conflict management, and what further changes may be likely in the coming years? With this volume we wanted to understand how peace operations have been adapting, especially since the turn of the century, in response to macro-level systemic changes, and we wanted to explore if we can detect any trajectories that help us anticipate how peace operations are likely to continue to evolve over the coming decades.

\footnotetext{
C. de Coning $(\square)$

Norwegian Institute of International Affairs (NUPI), Oslo, Norway

e-mail: cdc@nupi.no

(C) The Author(s) 2019

C. de Coning and M. Peter (eds.), United Nations

Peace Operations in a Changing Global Order, https://doi.org/10.1007/978-3-319-99106-1_15
} 
We have brought together a multidisciplinary and geographically diverse group of scholars and practitioners-some established authorities, others rising stars - to analyse the challenges and opportunities that UN peace operations are facing as a result of the uncertainty and turbulence of a global order in transition. Our ambition was to use this diversity of contributors to generate a variety of perspectives on the influences that shape peace operations. Together we have covered a range of topics that we thought are most critical to the evolution of peace operations in the twenty-first century.

Many of the contributing authors were engaged in some or other way with the UN High-level Independent Panel on Peace Operations (HIPPO) appointed by then UN Secretary-General Ban Ki Moon in 2014, to assess the state of peace operations. Ban Ki Moon tasked the Panel with making recommendations that would ensure that UN peacekeeping became fit for purpose again. The Panel produced its report in 2015, during a period when there was a sense in the diplomatic and research communities that the $\mathrm{UN}$, and in particular its peace operations, was struggling to live up to its expectations (Peter 2015). The prevailing view was that the scope and complexity of the challenges that have emerged have outgrown the capabilities of the UN (van der Lijn and Smit 2015).

The HIPPO Panel published its report in 2015 with far reaching recommendations for strengthening and revitalising the UN's approach to peace and security, and especially UN peace operations (UN 2015; Boutellis and Connolly 2016). At the same time as the HIPPO Panel undertook its review of UN peace operations, a ten-year review of the UN peacebuilding architecture took place (de Coning and Stamnes 2016), as well as a review of the implementation of UN Security Council Resolution 1325 on Women, Peace and Security. ${ }^{1}$ When these three reviews are read together, they provide a comprehensive overview and analysis of the key challenges facing UN peacekeeping, peacebuilding and the women, peace and security agenda a decade and half into the twenty-first century. Among others, they clearly show how inter-connected these agendas and approaches are, despite the fact that each is driven by its own political, bureaucratic, and scholarly interest groups.

In January 2017, a new Secretary-General, António Guterres, assumed office. The new UN Secretary-General immediately introduced a number

\footnotetext{
${ }^{1}$ For a summary of the major issues that these three reviews addressed, see Eli Stamnes and Kari Osland (2016).
} 
of changes to the way the UN is managed and coordinated. He opted for a cabinet-style executive committee to oversee the day-to-day management of the UN. He has appointed a special advisor on prevention and re-organised the executive office of the Secretary-General so that it can better serve as a central coordinating hub for the UN system. He has also instructed the geographical desks of the departments that deal with prevention, mediation, and peacekeeping, as well as the department that supports such operations and missions, to co-locate. The Secretary-General followed-up on these initial changes a few months later with three significant reform packages, one each on management, development, and peace and security. Many of these changes have been inspired by the recommendations of the peace operations, peacebuilding, and 1325 reviews, and is meant to make the UN more resilient in its ability to respond to some of the key challenges that have been highlighted and analysed in this volume.

Taken together, these reforms represent a significant system-wide effort to adapt the UN to both changes in the global order as well as the new emerging challenges facing the UN, and to enhance the effectiveness and efficiency of the United Nations. It is unlikely that António Guterres would have been able to introduce such sweeping changes to the way the UN system is managed and coordinated, if the ground work was not already done through the peace operations, peacebuilding and 1325 reviews, and the subsequent political direction from UN member states, which is reflected in, for instance, the sustaining peace resolutions that was approved by the Security Council and General Assembly in 2016 (UN 2016a, b). It is not certain, however, that these reforms will all be implemented. Several aspects of the reforms are experiencing push-back from certain member states or interest groups within the UN system. The degree to which the UN system will thus be able to adapt to both the challenges it faces in the short- to medium-term, and the changes underway over the medium- to long-term, is thus still very much an open question.

The various chapters in this volume explain why the UN system in general, and peace operations in particular, is under significant strain at this point in its evolution. We identify and analyse the scope and complexity of a number of the most significant drivers that place the UN system under stress. The preceding chapters explain how a combination of several interlinked factors-including the destabilising effects of violent extremism and the emergence of transnational organised crime as a conflict driver in areas such as the Sahel-meant that the UN, and its peace operations, had to manage increasingly complex conflict environments. If 
we add to these additional factors such as the impact of climate change, the increase in large-scale humanitarian emergencies, and the unprecedented high numbers of refugees and internally displaced persons they have generated, then the challenges the UN system as a whole has to deal with increase even further in scope and complexity.

These challenges have been compounded by internal UN stressors, such as the UN's failure to prevent the sexual abuse and exploitation committed by some of its peacekeepers; its inability to prevent South Sudan from relapsing into violent conflict despite the presence of a UN peacekeeping operation; its powerlessness to help consolidate the peace processes in Darfur and the Democratic Republic of Congo despite a decade long sustained effort by two of the largest operations in the history of the UN, and especially its mixed track record when it comes to protecting civilians in these conflicts.

There are also a number of deep structural tensions that undermine the credibility and effectiveness of UN peacekeeping. The most significant of these is the North-South divide between those who contribute the bulk of the peacekeepers, those that contribute most of the funding, and the patterns this creates when it comes to the kind of capabilities the UN has at its disposal, and those it cannot ever seem to get enough of, such as air assets and other force multipliers. Among others, these patterns - both those that influence the stock and flow of peacekeepers and those that restrict the resources necessary to enable them to achieve their mandates, and safeguard them while doing so-determine which countries bear the brunt of the burden when it comes to peacekeepers losing their lives in the interest of protecting the lives of others, and in maintaining international peace and security on behalf of all of us.

All these developments, and the new reforms introduced by SecretaryGeneral António Guterres, are taking place in the context of significant changes-what Adriana Abdenur refers to in her chapter in this volume as 'tectonic shifts' - that are underway at the global systems level. These changes are transforming the balance of power in the global order. In the last hundred years, we have seen the global order transform from a multipolar system into a bipolar order after the Second World War. At the end of the Cold War the global system changed again from a bipolar to a unipolar system, dominated by the United States and its allies. For the system of international governance, this meant that one ideology-neo-liberalismbecame the global norm, and global institutions like the UN became agents for the dissemination, implementation, and enforcers of this ideology. 
Currently we are witnessing yet another phase-shift. The unipolar era is waning in the face of a significant increase in the economic and political influence of countries like China and India in the global system. It is still uncertain what may replace it, but the next stage in the transition seems to be another multipolar era, in which several states-the United States, China, Germany, India, and Russia, to name a few-each have access to networks and forms of power sufficient to prevent any of the others from dominating the global order (de Coning et al. 2015). Another emerging characteristic of the transition is that several non-state actors, including some international and regional organisations, several large companies, and some non-governmental agencies, can exert significant influence on the global system on selected issues where they have a substantial capacity or competency. These changes at the global systems level have implications for the UN and for peace operations, and it is these implications that we set out to study in this edited volume.

\section{MaIn Findings}

In the Introduction we identified four developments at the global system level that are influencing the transformation of the global order, and we set out to study their implications for United Nations peace operations. The four transformational questions we asked, were:

- How is the rebalancing of relations between states of the global North and the global South impacting the UN's decision-making, financing and ability to design operations that go beyond the minimum common denominator;

- How is the rise of regional organisations as providers of peace impacting the primacy of UN peace operations and how and whether the UN can remain relevant in this era of partnership and competition;

- How have violent extremism and fundamentalist non-state actors changed the nature of international responses and what does this mean for previously advanced longer-term approaches to conflict resolution; and

- How are demands from non-state actors for greater emphasis on human security impacting UN's credibility and whether in light of the first three transformations the UN is even able to prioritise people-centred approaches over state-centred ones? 
The various contributors to this volume have analysed each of these trends in depth, and in the following section we will briefly consider some of their key observations and findings, and the implications for the future directions that UN peace operations may evolve towards.

\section{Relations Between the Global North and the Global South}

As Mateja Peter and Adam Day explored in their chapters, previous phase-shifts in the global order, such as from a bipolar to a unipolar world order at the end of the Cold War, have had a significant impact on UN approaches to peace. As Peter details, during the Cold War, UN peace operations were mostly limited to unarmed or lightly armed peacekeeping operations observing and monitoring cease-fires in the MiddleEast, Cyprus, and Kashmir. The UN operation in the Congo (ONUC), deployed from 1960 to 1964, was an exception, but it resulted in a further consolidation of the dominant trend of the period. Between 1948 and 1988, the UN deployed only 13 peacekeeping operations. During this period, peacekeeping was a military affair, and troops were mostly from countries that had no strategic interest in these conflict, such as Canada, India, Ghana, the Nordics, and Ireland. UN peacekeeping was clearly defined by its three principles - consent, impartiality, and the use of force only in self-defence- and enjoyed the support of the West, the Soviet-bloc and the Non-Aligned countries (see Mats Berdal in this volume).

The end of the Cold War saw a dramatic increase in the number of peacekeeping operations. Since 1988, the UN has deployed 57 peacekeeping operations, and the number of military and police peacekeepers increased from 11,000 in 1988 to a high point of 107,805 in 2015 . By 2018, this has decreased slightly, to 92,511 (Rappa 2018). The number of troop contributing countries also increased and changed significantly. Traditional peacekeeping contributors like Canada and the Nordics have reduced their defence budgets and they have shifted their contributions to NATO, to the extent that there are no longer any Western countries among the top 10 troop contributors. Africa and South East Asia now contribute the bulk of the peacekeepers. At the beginning of 2018, Ethiopia, Bangladesh, India, Pakistan, and Rwanda made up the top five contributors, and China was the largest contributor among the permanent members of the Security Council.

One of the significant changes that occurred since the end of the Cold War is the transformation of peacekeeping from being mostly engaged 
in cease-fire monitoring in inter-state conflicts, to being mostly involved in supporting the implementation of comprehensive peace agreements in intra-state conflicts in the 1990s. The emergence of a unipolar world order resulted in the UN becoming an important instrument in assisting state formation and state-building according to the dominant neo-liberal ideology of the time (Richmond 2004).

As a result of the dominance of this Western-led liberal consensus approach to international conflict management, the task of UN peacekeeping operations expanded significantly from cease-fire monitoring to the managing political transitions, which included disarming, demobilising and reintegrating ex-combatants, supporting constitutional writing processes, organising elections, supporting reconciliation processes, and helping to establish new state institutions. These new tasks resulted in another significant transformation, namely changing peacekeeping from mostly military into multidimensional operations that consisted of civilian, police, and military personnel (see Kari M. Osland in this volume).

Over time, notions of state security gave way to the concept of human security and in the 2000 s this resulted in a change in the core role of UN peace operations, namely a new focus on containing and mitigating the effects of intra-state conflicts on individuals, through new policy approaches to protection of civilians and stabilisation operations (Hilde F. Johnson in this volume and de Coning et al. 2017).

The current shift in the global order from a unipolar to a multipolar world order is thus likely to, once again, have significant effects on how UN peace operations evolve. It is still unclear what form these changes may take, but we can identify three drivers that are likely to inform the future direction of UN peace operations.

Firstly, it seems that some of the traditional North-South roles, that have been fixed into a predictable pattern since the end of the Cold War, may now start to change. Some of the countries that are likely to have a significant impact on the new global order, such as China and India, have been significant contributors of military and police personnel to UN peacekeeping operations, and they are likely to continue to support UN peacekeeping as an important instrument for managing global peace and security (see He Yin in this volume). China is now also the 2nd largest financial contributor to UN peacekeeping operations, and India's financial contribution will likely increase over time in proportion to its economic growth. The other major powers in the new multi-polar world order, such as the United States, Japan, the European Union, and Russia 
are all significant financial contributors to UN peacekeeping, but with the exception of a few European countries like Italy, they do not contribute significant number of troops. This is unlikely to change.

The US and the European countries have dominated the research and knowledge management dimensions and have played the leading role in determining the policy directions that UN peace operations have taken during the unipolar era. China and the other rising powers and emerging economies are increasingly signalling their intent to play a more prominent role in the policy and decision-making domain when it comes to UN peace operations ( $\mathrm{He}$ Yin in this volume and de Coning and Prakash 2016). These countries are thus likely to contribute more financially, and are likely to become more assertive in influencing the future policy direction of UN peace operations.

Secondly, in light of the uncertainty that the turbulence of a changing global order generates, and the lack of global trust that other security regimes like NATO suffer from, the UN Security Council and UN peace operations, despite their shortcomings, are likely to remain the most credible and reliable international instruments for maintaining international peace and security. As such, peace operations are likely to remain in high demand, and they are likely to remain under pressure to provide stability in conflicts characterised by violent extremism, organised crime and other forms of instability and conflict.

Thirdly, as the influence of the rising powers and the countries from the Global South more generally grow, the dominant neo-liberal ideology of the unipolar era will be increasingly challenged. As it is unlikely in a multipolar global order that agreement on an alternative globally endorsed common normative approach will emerge, one result is likely to be that UN peace operations would become less normative and less intrusive. ${ }^{2}$ In other words, UN peace operations are likely to stop prescribing the neo-liberal peace- and state-building models that were the norm during the unipolar era. In its place, peace operations are more likely to encourage home-grown or self-determined models for peaceand state-building, and are likely to concentrate on the more technical

${ }^{2}$ de Coning et al. (2015) argue that the Rising Powers are seeking to bring about an alternative global order that is based on a new pluralistic normative framework, which they refer to as coexistence, where different normative approaches are allowed to coexist and where the global order is designed to prevent the hegemony of any one ideology or normative approach over others. 
aspects of state-building (Call and de Coning 2017). Such technical solutions have not provided desired outcomes, and as Adam Day points out in his chapter, the UN would often achieve more with a light and nimble presence on the ground. This, according to Day, starts with the conflict prevention work.

It is also likely that UN peace operations will be tasked to concentrate more on physical security, law and order and the political dimensions of conflict management. However, this does not necessarily imply that peace operations are likely to become more robust or that the trend towards limited enforcement mandates will continue. The rising powers that are also major troop contributing countries, including China and India, are firm believers in the core principles of peacekeeping and the peaceful settlement of disputes (de Coning and Prakash 2016). Future UN peace operations are also likely to shift away from expansive mandates that include a broad range of capacity-building, peacebuilding, and state-building tasks (see Mateja Peter in this volume). The UN may still remain active in some of these areas, but more so via its development instruments, and more in support of nationally driven initiatives, rather than as an internationally driven normative agenda. Non-state actors are likely to play a greater role in this process (see Jonathan C. Agensky in this volume).

\section{The Rise of Regional Organisations}

One of the paradoxes of increasing globalisation is that it simultaneously seems to have stimulated the need for people to invest more in local and regional identities. In this volume, Thierry Tardy has addressed the impact of these developments in Europe, and I have addressed some of the developments in Africa. In my chapter, I describe how this trend manifested in a significant effort over the last two decades to develop Africa's peace and security architecture. Both the African Union and the European Union have invested in strengthening their early warning and prevention capacities, their ability to deploy mediators and special envoys, their ability to support countries emerging from conflict, and their ability to deploy peace support or crisis-management operations. The African Union has invested in establishing a peace operations standby capacity, the African Standby Force, and it has deployed and supported a dozen Africa-led operations over the past decade and a half. The EU has similarly invested in the EU Battle Group model and has 
deployed several missions of its own. In the process, both African-led peace operations and EU crisis-management missions have evolved beyond the UN peacekeeping model.

Over the last five years another type of security arrangement has emerged in Africa, what the AU now refers to as ad hoc security arrangements. In response to the threat posed by Boko Haram, a violent extremist group operating in northern Nigeria and neighbouring territories, the countries that make up the Lake Chad Basin Commission established the Multinational Joint Task Force (MNJTF). Following this model and faced with international terrorism and transnational organised crime in the Sahel region, Burkina Faso, Chad, Mali, Mauritania, and Niger formed the Group of Five (G5) Sahel joint force in 2017. The MNJTF and the G5 Sahel forces represent the latest generation of regional security arrangements that started with the AU's regional arrangement against the Lord's Resistance Army. It also drew inspiration from the early successes of the Force Intervention Brigade in the Democratic Republic of Congo, where countries from the SADC region (Southern African Development Community) came together to establish a robust brigade capable of containing and neutralising rebel groups such as the M23.

The trends that seem to be emerging from these experiences, at least in Africa, seem to be that where there is a need to counter a determined insurgency with force, the most effective response that can be mustered is to mobilise countries from the region that have a national security interest in the stability of the region, and whom are thus more willing to use force to counter terrorist or other violent threats, than forces organised via the UN peacekeeping model. And secondly, that by mobilising national forces to operate in their own border regions, and as necessary beyond their own borders in hot pursuit operations or in joint operations, these arrangements solve many of the force generation and use of force type challenges the UN faced elsewhere (see Mats Berdal in this volume).

As I argue in my chapter about Africa's role in peace operations, these adaptations of the UN peacekeeping model in Africa may contribute to an evolution of the international peace and security architecture. In the past, the UN was the sole internationally recognised actor when it came to maintaining international peace and security. In the future, regional organisations like the African Union and European Union are likely to take primary responsibility for maintaining peace and security in their 
own regions and immediate neighbourhood. The implication is that a new global peace and security architecture is emerging, where the UN, together with regional organisations, where they exist and are capable, are co-managing international peace and security. Thierry Tardy, in his chapter about the role of the European Union, argues that the European Union has embraced a conception of crisis management that is close to the UN's, and is willing to support such a global-regional peace and security partnership. Likewise, the Africa Union has signalled its willingness to increasingly take responsibility for peace and security in Africa. A new global peace and security architecture, based on the principle of regional subsidiarity, may thus be emerging. In the mean-time the $\mathrm{AU}$, EU and UN are cooperating closely in what the HIPPO has referred to as a new era of peacekeeping partnership (UN 2015).

\section{Violent Extremism and Fundamentalist Non-state Actors}

The previous Secretary-General of the United Nations, Ban Ki Moon, referred to peacekeeping as the flagship enterprise of the UN (2016a, b). However, he also recognised that UN peacekeeping is under severe pressure. UN peacekeepers are operating in very complex and dangerous environments (van der Lijn and Smit 2015; Karlsrud 2018). The UN mission in Mali (MINUSMA) is a good example of the kind of challenges UN peace operations face today, and by early 2018 , it has suffered the highest number of casualties in a UN operation in 20 years. The high number of fatalities and injuries is largely due to asymmetric terrorist attacks on the UN, including the use of improvised explosive devices.

As John Karlsrud argues in this volume, the threats the UN is facing are closely linked to the fact that it is not viewed as an impartial actor by the militant opposition groups, because its mandate involves helping the government in Bamako to extend its authority and control over the North of Mali. This puts the UN in direct confrontation with those armed groups and political factions campaigning for more autonomy for the North, and increasingly now also in the central region of Mali.

Scholars of armed conflict have long noted structural changes in the nature of conflicts, such as the proliferation of so-called new or hybrid war. In the post-Cold War period there is increasingly a blurring of war and crime. Arthur Boutellis and Stephanie Tiélès, in this volume, conclude that despite the recognition by the UN system and Member States that organised crime is a threat to peace and stability, particularly 
when in conjunction with terrorism and violent extremism, there is still much uncertainty about what the role of a multilateral organisation like the UN should be. In particular, the UN is uncertain about what UN peace operations could and should do about it. The issue has, however, become front and centre with almost three quarter of UN peace operations now operating in environments considered significantly affected by organised crime, particularly in the West Africa and Sahel contexts.

John Karlsrud in his chapter argues that the UN is neither principally nor operationally set up to fight terrorist groups by force. The HIPPO report drew a red line against a role for UN peace operations in counter-terrorism operations, saying that "UN peacekeeping missions, due to their composition and character, are not suited to engage in military counter-terrorism operations. They lack the specific equipment, intelligence, logistics, capabilities and specialized military preparation required, among other aspects" (UN 2015, p. 31). Karlsrud also points out that the Secretary-General has warned against a securitised approach to countering violent extremism, and has outlined a prevention agenda where the main goals must be to better understand the motivations for joining groups such as the IS; avoid using 'terrorism' as a label to eliminate political opposition; and deal with root causes through strengthening governance, the respect for human rights, more accountable institutions, service delivery and political participation. Kari Osland also points out in her chapter that the UN may be better served with a greater emphasis on trust-building in the local police rather than continued focus on the security aspects of their task.

Karlsrud, de Coning and others in this volume point out that coalitions of the willing, and in some instances regional organisations, seem to be the only mechanisms with the requisite political will, capabilities and staying power to conduct counter-terrorism operations. They point out however, that defeating violent extremism is not ultimately about military strength. Rather, it needs a holistic approach that addresses the root causes and drivers of the conflict. The comparative advantage of the UN lies in its convening power and impartiality, and its ability to provide and coordinate comprehensive support across the spectrum from its peace and security, development, and human rights pillars.

The implications for the future of UN peace operations are that UN peace operations are likely to be deployed in countries and regions where violent extremism and transnational organised crimes are dominant features of the security landscape (Williams 2016). However, it is unlikely 
that UN peace operations will be mandated to undertake counter-terror operations. It is more likely that they will accompany, or coexist alongside, other forces that do have such a role. In such contexts UN peace operations are likely to focus on seeking political solutions while using its development and peacebuilding pillars to support state and social institutions and civil society.

\section{Greater Emphasis on People-Centred Peace Operations}

UN peace operations have long been criticised for being too statecentric. They are deployed by a multilateral body of states, their military and police officers and units are contributed by states, and they are reliant on an international legal framework that enable their presence through formal status of forces and status of mission agreements between the UN and the host state. Since especially the end of the Cold War, many individual Special Representative of the Secretary-General and other mission leaders have taken steps to reach out to civil society and community leaders, and since the late 1990s UN peace operations have a civilian component-Civil Affairs-dedicated to sub-national outreach. However, these efforts were not enough to counter the many other drivers and incentives that ensured that UN peace operations were more sensitive to the needs of the host state, and other states in the international system, than to the people they were ultimately there to protect and serve.

As Youssef Mahmoud points out in his chapter in this volume, reaching out to people and engaging with local communities and ordinary citizens are common practices in many peace operations. However, these practices tended to take the form of ad hoc activities, without sufficient strategic focus or intent. Many community engagement activities remain mission-centric (e.g. winning hearts and minds of local populations) or as appendices to various state-centric goals such as restoring and extending state authority.

As emphasised in the HIPPO, the peacebuilding review, and the twin sustaining peace resolutions, for peace to be self-sustainable, it has to emerge from local social processes and it has to build on the social resilience that is already present in societies and communities (see also Jonathan Agensky in this volume). The implications for UN peace operations are that they should find new ways to contribute to broader international and local efforts that facilitate the re-emergence of the informal 
norms of behaviour and shared beliefs of societies and communities that are essential for institutions to be locally owned and embedded.

To sustain peace, UN peace operations thus have to develop new tools and capacities to engage not only with the state, but also with societies, communities and individual people. These need to include strong principled leadership, supported by the capacity to monitor the missions' actions and the effect they have on local communities and the everyday lives of the people they are meant to assist (Autesserre 2014). Missions should involve representatives of the societies they are working with when undertaking assessments, analysis, planning, programming, and evaluation. The nature of the involvement will depend on the context, but the principle of giving society maximum agency to influence the work of the mission, should be a general principle that guide peoplecentred peace operations. Missions should identify people that are generally perceived to be credible voices for their communities, such as traditional, civil society, religious and academic leaders, and involve them in the mission's engagement with its host society in a variety of ways.

Two groups that require special attention are women and youth. The HIPPO, the peacebuilding review, the Women, Peace and Security review, and the twin sustaining peace resolutions, all reaffirm the indispensable role of women in peacekeeping and peacebuilding. In particular they recognize the substantial link between women's full and meaningful involvement in efforts to prevent and resolve conflict, and those efforts' effectiveness and long-term sustainability. The larger the gender gap between the treatment of men and women in a society, the more likely it is that a country will experience conflict (United Nations and World Bank 2018, p. 30).

In recognition of the critical role that women play in all peace and security efforts, including in the UN, the new Secretary-General, António Guterres, has launched an initiative to encourage troop and police contributing countries to increase the number of women deployed in military and police contingents. At the same time, he recognizes that it is not just about the number of women in peacekeeping but also the role they play. He has set the example by, for the first time, achieving gender parity in all his senior appointments. The Secretariat has launched a senior women talent pipeline initiative to increase the number of women in senior peacekeeping positions.

The HIPPO and other reviews also recognizes the important role youth can play in the prevention and resolution of conflicts and as key 
driver of sustainability and inclusiveness. The Independent Progress Study on Youth and Peace and Security (United Nations 2018) provides a framework for partnering with and investing in young people to prevent violence, to promote their inclusion and to translate the demographic dividend into a peace dividend. The report recommends three mutually reinforcing strategies: First, it is critical to invest in young people's capacities, agency and leadership through substantial funding support, network-building and capacity-strengthening, recognizing the full diversity of youth and the ways young people organise. Second, systems that reinforce exclusion must be transformed in order to address the structural barriers limiting youth participation in peace and security. Third, partnerships and collaborative action where young people are viewed as equal and essential partners for peace must be prioritised.

The literature on the "local turn" in peace operations has highlighted the importance of local voices, but it has also presented a powerful critique of the potential challenges of focusing on the local (Mac Ginty and Richmond 2013; Mahmoud and Agensky in this volume). Peace operations should not be naive about the potentially challenging features of traditional forms of authority that can represent persistent structures of inequality. Local culture is important, but can also be a limiting factor or an element used to perpetuate systems of domination: "local actors and contexts can be partisan, discriminatory, exclusive and violent (as can international actors)" (Mac Ginty and Richmond 2013, p. 770).

There is still disagreement among some member states whether peace operations should be engaging directly with societies and people, grounded in concerns about how this could potentially undermine the authority of the host government. Few member states disagree that UN peace operations should continue to have the government as its principal partner. However, as the HIPPO pointed out, if sustainable and durable peace remains the main goal of peace operations, then enhancing state-society relations must be front and centre among the tasks that peace operations are supposed to carry out (UN 2015, p. 66). While, as pointed out above, many of the rising powers and emerging economies are likely to favour state-centric peace operations that do not prescribe a specific set of internationally agreed norms, most will likely agree that the ultimate aim of the UN should be to foster and support resilient societies.

At the same time, global civil society is also increasing in influence, and taken together with the spread of mobile phones and access to social 
media, the implications of the picture that is emerging is that UN peace operations will also increasingly be under pressure to be relevant and accountable to ordinary people, both in the countries where they are deployed, and in the rest of the world.

The pressure on UN peace operations to become more people-centred are thus likely to be irreversible and relentless. There are many ways in which UN peace operations can become more people-centred, including by involving representative advisory groups from civil society and local communities in assessments, analysis, planning, implementation, and evaluation, so as to ensure continuous direct input and feedback from the society on the work of the peace operation.

\section{Conclusion: Evolution, Adaptation, and Resilience}

Our core finding is that the increasing influence of China and several other new actors from the global South in the global governance system, has already started too, and is likely to continue to, generate a more pragmatic era of UN peace operations. This implies a shift away from using peace operations to help countries adopt neo-liberal-style institutions. In its place, peace operations are likely to become less intrusive and to become more supportive of locally-led and bottom-up solutions. At the same time, UN peace operations as an institution and a form of international conflict resolution is under increasing pressure. It needs to adapt its operations to a rise in violent conflict characterised by violent extremism and transnational organised crime. It must also reduce expenditures, improve effectiveness, and find new ways to improve internal accountability, in order to prevent scandals such as some of its peacekeepers sexually abusing the very people the UN is meant to protect. These internal or technical pressures, together with turbulence introduced by the transitions underway in the global order, has introduced a period of flux during which significant innovation and experimentation, including with new forms of peace operations, is possible.

In the various contributions to this edited volume, three main themes stand out. These-strategic political coherence, the employment of force, and the limits of peace operations-will drive the evolution of UN peace operations in the coming decades.

First, strategic political coherence relates to the HIPPO's emphasis on the primacy of politics, that is the recognition that peace operations always serve a political purpose, and that there is rarely a sustainable 
solution that does not boil down ultimately to a negotiated political agreement (see Adam Day in this volume). However, strategic coherence also refers to the new reality that the UN, and UN peace operations, will rarely, if ever, operate on its own in the future. In every theatre it will operate alongside other international and regional actors, each with its own mandate, responsibility, and comparative advantages. The HIPPO framed it as a new era of networked peace operations. The UN system, and UN peace operations, now need to adapt to this new reality and develop the capacity to play its role, which may often include the convening role, in a network of national and international efforts.

In this new system-of-systems reality, several international actors, including the World Bank and other regional development banks, bilateral donors, the EU, and other regional organisations each play an important role alongside national and local actors. It is the combined and cumulative role of all of these national and international actors together that constitute the larger political project. UN peace operations need to understand its role in this larger political project, and it needs to have the capacity to support the effort necessary to coordinate, track and take stock of this larger political project. The complexity of maintaining overall strategic political coherence among these various systems-within-systems should not be underestimated. Nor can it be avoided as it is the organising feature of global governance in the twenty-first century. The performance of UN peace operations will thus not be judged only on the ability of the mission to carry out its own civilian, police, and military tasks. Nor will it be enough to be integrated with the rest of the UN system. In future, effectiveness will also depend on the degree to which a UN peace operation contributes to the strategic political coherence of the larger national and international effort to sustain the peace in a given country or region.

Second, the employment of force seems to remain one of the key defining challenges of UN peace operations. How force is employed in UN peace operations is one of the key features that distinguishes it from AU, EU and NATO peace support operations. As Mateja Peter points out in this volume, the principled approach to the use of force in UN peace operations has been one of its most resilient features. Whenever the UN has deviated from this norm, for instance in the 1960s during the ONUC mission in the Congo, or more recently in the Central African Republic, the Democratic Republic of the Congo, and Mali, the norm seems to be validated and reinforced. This does not mean that the 
Security Council is unlikely to continue to task UN peace operations, as a last resort, with enforcement or stabilisation operations (de Coning et al. 2017). It does imply, however, that the principled approach to UN peace operations, including the minimum use of force principle, is likely to remain one of the defining features of UN peace operations (Mats Berdal in this volume and Karlsrud 2018). As discussed earlier in this concluding chapter, not only are rising powers like China and India in favour of maintaining this principled approach, but the HIPPO has also argued against utilising peace operations in counter-terrorism and other enforcement roles, on the basis that the inherent features of UN peace operations, including its globally diverse force generation structure, its civilian logistics chain, its multilateral financing system and its political command and control mechanism, make it unfit for combat operations.

Third, debates about what the outer limits of UN peace operations should be, seems to be one of the features of UN peace operations that is constantly adapting to changing requirements. When peacekeeping started it was mostly unarmed or lightly armed military observers or units that implemented and monitored cease-fire agreements. More complex tasks were added over time, including supporting the implementation of comprehensive peace agreements, facilitating the birth of new states, and the protection of civilians. Police and civilian experts were added and peacekeeping became multi-dimensional. During the unipolar era, UN peace operations became a key facilitator for the adoption of neo-liberal state institutions. UN peace operations organised elections, oversaw the writing of new constitutions, helped to develop rule of law and promoted western-style multiparty democratic models. While several peacekeeping missions ended successfully during this period in places like Angola, Cambodia, Guatemala, Mozambique and Namibia, criticism started mounting in the 2000s against the seeming inability of mission like the UN mission in the Democratic Republic of the Congo and the joint AU and UN mission in Darfur to reach a fitting end.

Together with increasing pressure on the funding of peace operations questions are increasingly being raised about the scope of peace operations. Why do some contemporary peacekeeping missions have responsibility for justice, police and corrections and other governance functions? Should they have human rights mandates? Why is the support for elections part of UN peace operation missions, why should it not be the role of, for instance, the UN Development Programme (UNDP)? Thus far the reasons why many of these functions were included in UN 
peace operations seem to have more to do with the assessed contribution funding model of UN peace operations than with any theory of change model. Many of these efforts are simultaneously also supported by UN agencies, funds, and programmes, as well as other bilateral donors, regional organisations, and international and national NGOs. This debate seems to be leaning towards the side that argues for a new era of limited UN peace operations, where these operations should be focused on fewer priority areas, mainly protection, stability, and politics, organised around functions unique to UN peace operations, or at least functions that UN peace operations have a comparative advantage in. This debate will be one of the most important debates for UN peace operations in the years to come. It is also likely to be one of the most contentious, because it has financial implications, it involves the roles of other UN agencies, and also because member states have widely divergent opinions about what the role of UN peace operations should be.

While one of the characteristics of UN peace operations has been the resilience of the idea, defined by its three core principles, another has been the continuous evolution of the specific manifestations of that idea into practice. UN peace operations have shown a proven capacity to continuously adapt to new challenges. If there is one thing we can predict with a fair amount of certainty, then it is that UN peace operations will continue to adapt and evolve in response to changes in the global order, to the way the nature of conflict develops, and to the internal reforms in the UN system, and yet it will also remain resiliently identifiable as UN peace operations.

\section{REFERENCES}

Autesserre, Séverine. 2014. Peaceland: Conflict Resolution and the Everyday Politics of International Intervention. Cambridge: Cambridge University Press. Boutellis, Arthur, and Lesley Connolly. 2016. The State of UN Peace Operations Reform: An Implementation Scorecard. New York: International Peace Institute. Call, Charles T., and Cedric de Coning (eds.). 2017. Rising Powers and Peacebuilding. London: Palgrave.

de Coning, Cedric, and Chander Prakash. 2016. Peace Capacities Network Synthesis Report: Rising Powers and Peace Operations. Oslo: Norwegian Institute of International Affairs.

de Coning, Cedric, and Eli Stamnes (eds.). 2016. UN Peacebuilding Architecture: The First Ten Years. Abingdon: Routledge. 
de Coning, Cedric, Chiyuki Aoi, and John Karlsrud (eds.). 2017. UN Peacekeeping Doctrine in a New Era: Adapting to Stabilisation, Protection and New Threats. New York: Routledge.

de Coning, Cedric, Thomas Mandrup, and Liselotte Odgaard (eds.). 2015. The BRICS and Coexistence: An Alternative Vision of World Order. Abingdon: Routledge.

Karlsrud, John. 2018. The UN at War: Peace Operations in a New Era. London: Palgrave.

Mac Ginty, Roger, and Oliver P. Richmond. 2013. The Local Turn in Peace Building: Acritical Agenda for Peace. Third World Quarterly 34 (5): 763-783.

Peter, Mateja. 2015. Between Doctrine and Practice: The United Nations Peacekeeping Dilemma. Global Governance: A Review of Multilateralism and International Organizations 21 (3): 351-370.

Rappa, Ryan. 2018. Reversing the Trend: UN Peacekeeping in 2017. Global Peace Operations Review. In Focus, March 27.

Richmond, Oliver P. 2004. UN Peace Operations and the Dilemmas of the Peacebuilding Consensus. International Peacekeeping 11 (1): 83-101.

Stamnes, Eli, and Kari Osland. 2016. Synthesis Report: Reviewing UN Peace Operations, the UN Peacebuilding Architecture and the Implementation of UNSC 1325. Oslo: NUPI.

United Nations. 2015. Uniting Our Strengths for Peace-Politics, Partnerships and People, Report of the High-Level Independent Panel on United Nations Peace Operations. New York: United Nations.

United Nations. 2016a. United Nations General Assembly Resolution 70/262. New York: United Nations.

United Nations. 2016b. United Nations Security Council Resolution 2282. New York: United Nations.

United Nations. 2018. The Missing Peace: Independent Progress Study on Youth and Peace and Security. New York: United Nations.

United Nations, and World Bank. 2018. Pathways for Peace: Inclusive Approaches to Preventing Violent Conflict. Washington, DC: World Bank.

van der Lijn, Jair, and Timo Smit. 2015. Peacekeepers Under Threat? Fatality Trends in UN Peace Operations. Stockholm: Stockholm International Peace Research Institute.

Williams, Paul. 2016. The Peace Operations Challenge for the Next SecretaryGeneral. New York: International Peace Institute Global Observatory. 
Open Access This chapter is licensed under the terms of the Creative Commons Attribution 4.0 International License (http://creativecommons.org/licenses/ by $/ 4.0 /$ ), which permits use, sharing, adaptation, distribution and reproduction in any medium or format, as long as you give appropriate credit to the original author(s) and the source, provide a link to the Creative Commons license and indicate if changes were made.

The images or other third party material in this chapter are included in the chapter's Creative Commons license, unless indicated otherwise in a credit line to the material. If material is not included in the chapter's Creative Commons license and your intended use is not permitted by statutory regulation or exceeds the permitted use, you will need to obtain permission directly from the copyright holder.

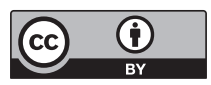

